\title{
Livestock Management and Gendered Decision-Making in Rural Cambodia
}

\author{
John Walsh \\ Shinwatra University Thailand \\ jcwalsh100@hotmail.com
}

\begin{abstract}
Agricultural households tend, around the world, to have gendered divisions of work depending on a range of historical, practical, cultural and geographic factors. Once the issue of who does what in the household is determined, it tends to remain that way and this means it is difficult to introduce development-positive changes in the household in the absence of a moment of change. This paper investigates whether there are opportunities for such change in the case of livestock management in Cambodia. A total of 200 interviews were conducted in four rural areas of Cambodia using a specially designed questionnaire. The extent and spread of livestock ownership was investigated together with the issue of who in the household takes responsibility for different aspects of that management. It is found that there is some limited scope for introducing change in households through changing the opportunities for livestock agriculture in Cambodia.
\end{abstract}

Keywords: Agriculture, Cambodia, development, gendered division of labor, livestock

\section{Introduction}

Women make production-related decisions to different extents in different societies and cultures (Acharya \& Bennett, 1983). In cultures in which men hold structurally superior status positions in households, bargaining model and resource theory approaches are not as relevant as cultural approaches to understanding decision-making behavior (Kriti, Tisdell and Roy, 2003). Nevertheless, decision-making ability raises women's status and may lead to better long-term developmental outcomes, especially if it is a part of reducing gender inequality (World Bank, 2012). State agencies wishing to foster economic development should, therefore, consider ways to encourage more decision-making by women. Livestock management is an essential part of many rural household survival strategies and contains much gendered knowledge (Rocheleau, 1991; Yisehak, 2008). Are there areas of livestock management where gendered knowledge can be changed through receiving new information or having to make unprecedented decisions? This is the question that spurs the research reported on in this paper, which involved a quantitative study of women in rural households in two provinces of Cambodia. Cambodia exhibits above average levels of gender discrimination and does so more than its neighbors (Chan \& Chheang, 2008) and is also a low income country entering a new era of economic development as factories open and infrastructure is built, despite spending less on education for young people in terms of GDP than any other Asian country apart from Lao PDR (ADB, 2014:53). Agriculture remains the most important sector in the economy and there is considerable scope for promoting higher levels of gender quality as a means of enhancing inclusive growth. Cambodia is also considered to be a post-conflict society, since it was devastated by warfare leading to the victory of the Khmer Rouge or Cambodian Communist Party and its subsequent rule from 1975-9. Millions of people were killed or displaced during this period and reconciliation subsequently has been partial at best. The paper continues with a review of relevant literature, a description of the methods employed in the research and then a presentation of the findings and a discussion of their meaning.

\section{Literature Review}

Decision-Making: The understanding of the nature of decision-making by individuals varies depending on the field of study within which the discussion takes place. Within the field of economics, decision-making is thought to be conducted within the framework of rational expectations. People collect all information necessary to make their decision, weigh up the options depending on which will yield the greatest utility in their own interest and then choose accordingly (Davidson, 1982). In some cases, the basic framework is 
supplemented by the concept of satisficing (Simon, 1955), which explains that not only is it impossible for an individual actually to gather all the information required to make a decision according to the rational expectations framework but that it would actually go against the interests of the individual to try to do so. Instead, people will satisfy themselves - i.e. gather some information so as to give the impression that the process has been followed and then consider that sufficient. This may be seen in the common business practice of asking for quotes from three different companies before making a purchasing decision rather than seeking to research every possible supplier. In recent years, work on information asymmetries and their impact on decision-making by economists such as George Akerlof, Michael Spence and Joseph Stiglitz has been considered sufficiently revolutionary as to have won them the Nobel Prize for the discipline for 2001. The problems of information overload and information poverty in decision-making are linked and satisficing behaviour is a rational response to trying to find a solution.

In the social sciences, decision-making is considered to include not just behavioral aspects but also environmental factors. The utility-maximization approach derived from microeconomics is rejected because it is obvious from day-to-day experience that people will routinely sacrifice their own self-interest for that of their loved ones and will also practice deferral of satisfaction, while many decisions that people do make can only be described as non-rational or even irrational. In some cases, these decisions can be understood by incorporating into the model of decision-making behaviour variables relating to psychological, psycho-social and ideological states of mind. This has been taken to its most comprehensive extent within the field of marketing. Marketing models of consumer behaviour (which is distinct from organizational decision-making, which has its own set of practices and procedures) are powered by the commercial imperative of predicting how people will act so as to be able successfully to sell products to them and also by the computing power of contemporary machines which can integrate numerous complex variables and constructs within factor analysis that can group into lifestyle and psychographic segments a large number of individuals (Reynolds \& Gutman, 1988). The model incorporates additional factors such as antecedent states, auditory and olfactory stimuli, reaction to colors, presence of other people and so forth (e.g. Donovan et al., 1994; Baumeister, 2002; Belk, 1975). It is evident, in other words, that decision-making can be a complex procedure, consisting of various stages and procedures.

For the current research, a model of decision-making is adopted that recognizes a plurality of relevant inputs and stages, from problem (or issue) recognition, information gathering, criteria evaluation, commitment and post-decision assessment and reassessment. This is a naturalistic approach to decision-making that is based on close observations of people in real-world situations (Klein \& Zsambok, 1997). This features ill-defined objectives and ill-structured tasks, with people who are experienced in decision-making under constantly changing conditions and with a focus on finding solutions that are workable under current circumstances.

Gender and Decision-Making: As previously mentioned, there is reason to assume that gender and decision-making at the household level are interrelated. There are three strands of literature that may be used to support this hypothesis:

- Development studies: gender-based oppression remains an important area of investigation with development studies both in its own right and in terms of the practicalities of what disempowerment might mean in practice (Karl, 1995). Research in this area has, therefore, both an ideological and a practical purpose. This project focuses on the practical aspects of gendered decision-making. For example, research has indicated that the adoption of new technologies by men is more likely to be affected by the attitude towards the technology, while women are more likely to take into account behavioral control and subjective norms (Venkatesh, Morris \& Ackerman, 2000). In the context of Thailand, quantitative research has indicated the relevance of gender in expectation formation and behaviour with respect to migration (De Jong, 2000).

- The second strand of literature relevant to this hypothesis is derived from the world of micro-finance initially created by the work of Muhammad Yunus and the Grameen Bank. One of the features of the micro-sized lending scheme has been that it prioritizes accepting women as clients since they are more likely to spend the money on the activities on which the application was made and to be more conscientious about making repayments on time. There is a variety of practical reasons which might explain why this could be the case. Research elsewhere certainly suggests that, particularly in the context of a developing nation with open borders such as Nepal, women are much more likely to have to 
remain at home and deal with dependent family members, while men are comparatively free to abandon their responsibilities (Thakur \& Walsh, 2013).

- The third strand in the literature that relates to the role of women in the household may be found in the work of the British sociologist Richard Hoggart. His work (e.g. Hoggart, 1996) focuses in part on the importance of strong women in working class households and how they are able to keep the household functioning despite numerous and unpredictable financial and other shocks. In his view, they provide the counterbalancing force to the precarious image of the peasant who, in the image conjured up by Scott (1976), wades across the landscape up to his chin in water, when any disturbances can lead to him being swept away or drowned. It is important that the international nature of Hoggart's work be stressed because there may otherwise be a tendency to concentrate on descriptions of Khmer women in the past and their relative freedoms, in reports dating back to the $\mathrm{C} 13^{\text {th }}$ Chinese ambassador Daguan (2007) which can incorporate a degree of essentialism - i.e. there is something unique and essential in Khmer society that sets it apart from any others.

As a result of these different strands of the literature, it was deemed appropriate to explore the role of gender in decision-making. As suggested above, decision-making is a complex and multi-step process that evolves with respect to learning, new knowledge acquisition and changes in the external environment. However, it seems likely architecture of decision-making tasks will come into force which means people will tend to make the same decisions repeatedly, especially when the issue concerned is of some importance. This is consistent with a theory of decision-making that is related to bargaining theory (Manser \& Brown, 1980). However, there is a strong strand in the literature that stresses the importance of processes rather than roles (e.g. Davis, 1976) and, if this is the case, the role of the HH would not always be paramount. This study focuses on moments of change as occasions when the settled architecture of decision-making may change - perhaps for the better if this means that women are given more decision-making power as a result and gender inequality is reduced.

Head of the Household: Cambodia, in common with many East Asian countries, uses a household registration system that requires families to identify a specific head of the household. This is normally the senior male member of the household, whether or not he is a permanent resident. If the previous head should die or in some other way become excluded from the household, then the status may be conferred on another member automatically in non-problematic situations or after a process of negotiation if required. In the history of Khmer (Cambodian) society, household membership and indeed familial relationships have commonly been subject to complex and fluid sets of circumstances (Jacobsen, 2008) and this has contributed to ambiguity that has continued into contemporary society, despite the various attempts at modernization that have been made. Nevertheless, the status of head of household does carry some legal implications and individuals recognize that there should be a designated individual fulfilling this role. The methodological and epistemological difficulties evident in different concepts and forms of understanding across societies (Budlender, 2003) are acknowledged.

It is evident that head of the household $(\mathrm{HH})$ status indicates some influence in decision-making activities. The variable was operationalized in the following way: initially, the fieldwork team was instructed to seek out within the various villages that they visited households where women were the heads as much as possible and, when not possible, to interview a senior woman in the household. When a woman was identified as the $\mathrm{HH}$, because she was divorced or widowed or never married, then this was relatively unproblematical. When a man was present and the senior woman was identified as his wife (which was overwhelmingly the most common pattern), then he would be identified as the HH. However, owing to the importance of labor migration, a question was added to determine whether the man who was designated as the $\mathrm{HH}$ was away from home and, consequently, the principal woman should be identified as the HH. However, a small number $(n=3)$ observed during the interview that, although they lived in a household in which the male HH was away from home for a significant period of time, he nevertheless should be considered the $\mathrm{HH}$ because he represented the principal decision-maker in the areas investigated. Examination of the results showed an unequal distribution of the gender of the $\mathrm{HH}$ in the different provinces. In Takeo, 48 of the $90 \mathrm{HH}$ were male (53.3\%, while in Kampong Thom the figures were 76 out of $110(69.1 \%)\left(n=0.022^{*}\right)$. This is presumed to be the result of labor migration, which has stronger pull in the poorer province and provides more opportunities for women to be $\mathrm{HH}$, whether they wish to be so or not. A total of 37 respondents reported that they were 
married but that their husbands lived away and so they were accorded HH status. There were no significant differences between the two provinces in this regard.

\section{Methodology}

This study employs a quantitative approach to investigate the relationship between gender and decision-making behaviour with respect to livestock in a sample of rural households in Cambodia. A total of 200 questionnaires in total were completed. The sample was drawn from two different provinces of Cambodia - Takeo and Kampong Thom - so as to assess whether both inter-province and intra-province differences were influential. Consequently, two areas were identified in each province and villages sampled within each of the four areas. The samples sizes collected were as follows:

Table 1: Sample Locations; source: Original Research; $\mathbf{n}=\mathbf{2 0 0}$

\begin{tabular}{lll}
\hline & Number of Interviews & \\
\hline Province & Area A/B & Area C/D \\
Takeo & 45 & 45 \\
Kampong Thom & 56 & 54 \\
\hline
\end{tabular}

The slight under-representation of Takeo is explained by the fact that the first testing of the questionnaire and methodology took place in that province and so data collection was not so efficient at that stage. When intra-province analysis is described in the text following, areas A and B belong to Takeo province and areas C and $\mathrm{D}$ belong to Kampong Thom province. The interviewers were instructed to obtain a diverse selection of farm sizes within the villages that had been identified. The sampling strategy was a combination of purposive and convenience in nature. The importance of inter- and intra-provincial comparisons was indicated by both the initial pre-survey qualitative research (personal interviews) and the desk research, which saw secondary sources of information, including academic papers, information from governmental agencies and non-governmental organizations (NGOs) and reputable media sources, integrated into the project database.

Questionnaire Development: An initial version of the questionnaire had been developed and extensively tested in an earlier study which employed similar techniques and methodological assumptions as those that have been used in this study (Lovichakorntikul, Ngamsang \& Walsh, 2013). The first version of the questionnaire was written in English and then interpreted into Khmer for the fieldwork. It was then amended for this survey with question sections on livestock ownership and management added to replace no longer needed sections. In doing so, question structures, wordings and order followed predecessors as far as possible. This questionnaire was interpreted into Khmer for testing and then implementation. In the field, its use proved to be practicable and respondents, with the usual difficulties able to be overcome were willing to contribute to the research process.

Fieldwork: The fieldwork was handled by a designated team, led by an experienced member of Pannasastra University in Phnom Penh, who was briefed and then trained the fieldwork team in the presence of the principal investigator. The fieldwork team was composed of undergraduate students at leading universities in Phnom Penh, the capital of Cambodia, who were recruited directly by the fieldwork supervisor on the basis of their maturity and experience, English language ability and availability for fieldwork in distant provinces. Training by the principal investigator and fieldwork supervisor was followed by one day of pilot testing involving the fieldwork team and supervisor and a representative of the funding agency. At each stage, careful note of progress was made and the method and means of conducting the questionnaires adjusted where necessary. It was determined that only minor changes were required in each case.

\section{Results and Data Analysis}

Once the questionnaires were completed, any open text questions and others where Khmer language had been used were interpreted into English and then sent to the principal investigator. The questionnaires were then checked before being entered into an industry standard software program, when double checking of data entry took place. Subsequently, various statistical tests and techniques were employed to produce the results that are reported in this paper. The principle of parsimonious investigation was employed, which 
requires the minimum number of variables and tests necessary to formulate hypotheses and their testing, following the lines of Occam's Razor.

Livestock Ownership: Most households (75.5\%) possessed chickens and cattle (60.0\%), while the presence of pigs $(27.5 \%)$, poultry (16.0\%) and buffaloes (10\%) was also noticeable (see Table 2 below).

Table 2: Livestock Ownership; Source: Original Research; $\mathbf{n}=200$

\begin{tabular}{|c|c|c|c|c|}
\hline Animal & $\begin{array}{l}\% \text { of households } \\
\text { keeping animals }\end{array}$ & $\begin{array}{lr}\begin{array}{l}\text { Ave number } \\
\text { animals }\end{array} & \begin{array}{r}\text { of } \\
\text { per }\end{array} \\
\text { household } & \end{array}$ & $\begin{array}{l}\text { Average number of animals } \\
\text { in households keeping them }\end{array}$ & SD \\
\hline Chickens & 75.5 & 9.47 & 12.54 & 12.05 \\
\hline $\begin{array}{l}\text { Poultry } \\
\text { (ducks/geese) }\end{array}$ & 16.0 & 4.24 & 26.50 & 87.33 \\
\hline Pigs & 27.5 & 0.86 & 3.11 & 4.22 \\
\hline Sheep/goats & 0 & 0 & 0 & - \\
\hline Cattle & 60.0 & 1.67 & 2.78 & 1.74 \\
\hline Buffaloes & 10.0 & 0.34 & 3.35 & 2.18 \\
\hline Fish (in pond) & 1.5 & 6.00 & 400 & 528.77 \\
\hline
\end{tabular}

Subsequent analysis revealed that there were some differences in household livestock management based on the area within the province.

Table 3: Breakdown by Province of Livestock Ownership; source: Original Research, $\mathbf{n}=\mathbf{2 0 0}$

\begin{tabular}{lllll}
\hline $\begin{array}{l}\text { \%age of households } \\
\text { reporting } \\
\text { ownership }\end{array}$ & Takeo -A & B & $\begin{array}{l}\text { Kampong Thom - } \\
\text { C }\end{array}$ \\
\hline Chickens & 84.4 & 68.9 & $66.1^{*}$ & $83.3^{*}$ \\
Ducks/Geese & 11.5 & 6.7 & 23.2 & 20.4 \\
Pigs & $26.7^{*}$ & $51.1^{*}$ & $7.1^{* *}$ & $29.6^{* *}$ \\
Cattle & 75.6 & 71.1 & 50.0 & 48.1 \\
Buffaloes & 0 & 0 & $25.6^{*}$ & $7.4^{*}$ \\
Fish & 2.2 & 4.4 & 0 & 0 \\
\hline
\end{tabular}

Ducks and geese were significantly more likely to be owned in Kampong Thom (21.8\%) than in Takeo (8.9\%) ( $\operatorname{sig}=0.010^{*} ; \mathrm{n}=200$ ), although pigs were significantly more common in Takeo (38.9\%) than Kampong Thom $(18.2 \%)\left(\mathrm{sig}=0.001^{* *} ; \mathrm{n}=200\right)$ and so were cattle $(73.3 \%$ to $49.1 \%)\left(\mathrm{sig}=0.000^{* *} ; \mathrm{n}=200\right)$. Interestingly, buffaloes were only found in Kampong Thom ( $\operatorname{sig}=0.000^{* *} ; \mathrm{n}=200$ ) and the three fish ponds were found in Takeo ( $\operatorname{sig}=0.089 ; n=200$ ). On the whole, then, there is evidence of differential patterns of livestock ownership based on geographical factors. This is further indicated by the pattern of rice agriculture (see Table 4 below).

Table 4: Area Breakdown of Rice Cultivation; source: Original Research; $\mathbf{n}=\mathbf{2 0 0}$

\begin{tabular}{lllll}
\hline $\begin{array}{l}\text { \%age of households } \\
\text { growing this type of rice }\end{array}$ & Takeo - A & B & $\begin{array}{l}\text { Kampong Thom - } \\
\text { C }\end{array}$ \\
\hline Early Wet Season Rice & $31.1^{*}$ & $55.6^{*}$ & $39.3^{* *}$ & $1.9^{* *}$ \\
Wet Season Rice & 91.1 & 97.8 & $66.1^{*}$ & $85.2^{*}$ \\
Dry Season Rice & 4.4 & 2.2 & 5.4 & 0 \\
Receding Rice & 2.2 & 0 & $41.1^{* *}$ & $5.6^{* *}$ \\
Floating Rice & 0 & 0 & 0 & 0 \\
\hline
\end{tabular}

Early wet season rice was significantly more likely to be grown in Takeo (43.3\%) than in Kampong Thom $(20.9 \%)\left(\mathrm{sig}=0.001^{* *} ; \mathrm{n}=200\right)$, as was also wet season rice $(94.4 \%$ to $75.5 \%)\left(\mathrm{sig}=0.000^{* *} ; \mathrm{n}=200\right)$, while receding rice was significantly more likely to be grown in Kampong Thom $(23.6 \%)$ than Takeo $(1.1 \%)$ (sig = $0.000^{* *} ; \mathrm{n}=200$ ). It is also noticeable that the mean size of land used for rice cultivation is much higher in 
Kampong Thom than in Takeo, to the extent of 22,826.1 $\mathrm{m}^{2}$ and $21,115.7 \mathrm{~m}^{2}$ for early wet season rice and wet season rice compared to $6,629.2$ and $6,557.7 \mathrm{~m}^{2}$ respectively. Further, $98.0 \%$ of farmers in Takeo will conduct rice agriculture compared to $88.2 \%$ in Kampong Thom ( $\mathrm{sig}=0.003^{* *} ; \mathrm{n}=200$ ), while $11.1 \%$ of Takeo farmers rented additional land to grow rice, compared to $31.8 \%$ of farmers in Kampong Thom (sig $=0.000^{* *} ; \mathrm{n}=200$ ). It is noticeable, therefore, that specific land conditions have an important part to play in patterns of agriculture. As previously noted, the presence of irrigation can make a dramatic difference in prospects for agriculture and this can be sporadically distributed across the countryside. There appear to be other factors that are equally location-specific.

Gender and Livestock Management: Respondents were asked questions about who was the primary career for each type of livestock kept and who made decisions about them. The tables below display the results broken down by the gender of the HH (see Tables 5-9). It is evident that women have an important role to play in managing livestock in the sample. The degree of responsibility varies from animal to animal but even in the case of cattle and buffaloes, in no more than $40 \%$ of all households were men solely or mainly charged with principal responsibility for care or decision-making (Tables 8 and 9). In the case of chickens and other poultry (Tables 5 and 6), women have majority of the responsibility for care and decision-making and their role with the pigs (Table 7) was also very evident (of course, the opinions of other household members are not available to triangulate these results). It is also noticeable that in some $10-20 \%$ of the cases, other household members have primary responsibility for taking care of livestock but they have very little or no decision-making power. It is suggested that this indicates that it is younger people or children who are involved in this category. Many of the distributions shown in these tables are statistically significant and it is evident that this is much more likely to occur in the cases of chickens and cattle, which have larger sample sizes. It seems probable that the other forms of livestock would also demonstrate statistically significant distributions if there were larger sample sizes. The statistical significance indicates that the proposition that the distribution is random can be rejected. Instead, the distributions are meaningful and may be interpreted as such. The following section provides a discussion of the findings to date.

Table 5: Gender and the Management of Chickens; source: Original Research

\begin{tabular}{|c|c|c|c|c|c|c|c|c|c|c|c|c|c|c|c|}
\hline \multirow[b]{2}{*}{ (\%age) } & \multicolumn{3}{|c|}{$\begin{array}{l}\text { Who decides to raise } \\
\text { these animals? }\end{array}$} & \multicolumn{3}{|c|}{$\begin{array}{l}\text { Who bargains the } \\
\text { price when buying? }\end{array}$} & \multirow{2}{*}{$\begin{array}{l}\text { Who } \\
\text { care? } \\
\text { M }\end{array}$} & \multirow{2}{*}{$\begin{array}{r}\text { takes } \\
\text { F }\end{array}$} & \multirow{2}{*}{$\begin{array}{r}\text { rimary } \\
\text { Total }\end{array}$} & \multicolumn{3}{|c|}{$\begin{array}{l}\text { Who decides when to } \\
\text { sell the animals? }\end{array}$} & \multicolumn{3}{|c|}{$\begin{array}{l}\text { Who bargains the price } \\
\text { when selling? }\end{array}$} \\
\hline & M & $\mathbf{F}$ & Total & M & $\mathbf{F}$ & Total & & & & $\mathbf{M}$ & $\mathbf{F}$ & Total & M & $\mathbf{F}$ & Total \\
\hline $\begin{array}{l}\text { Only/mainly } \\
\text { man }\end{array}$ & 23.6 & 9.7 & 17.9 & 22.5 & 11.3 & 17.9 & 11.2 & 6.4 & 4.6 & 16.9 & 8.1 & 13.2 & 16.9 & 12.9 & 8.6 \\
\hline Joint & 19.1 & 8.1 & 14.6 & 7.9 & 4.8 & 6.6 & 25.8 & 11.3 & 19.9 & 11.2 & 8.1 & 9.9 & 3.4 & 3.2 & 3.2 \\
\hline $\begin{array}{l}\text { Only/mainly } \\
\text { woman }\end{array}$ & 49.4 & 56.4 & 52.3 & 60.7 & 61.3 & 60.9 & 52.8 & 45.1 & 49.7 & 62.9 & 61.3 & 62.3 & 71.9 & 59.7 & 66.8 \\
\hline $\begin{array}{l}\text { Other } \mathrm{HH} \\
\text { member }\end{array}$ & 7.9 & 6.5 & 7.3 & 9.0 & 3.2 & 6.6 & 10.1 & 17.7 & 13.2 & 9.0 & 3.2 & 6.6 & 7.9 & 4.8 & 2.0 \\
\hline $\begin{array}{l}\text { Only/mainly } \\
\text { respondent }\end{array}$ & 0 & 9.7 & 4.0 & 0 & 6.4 & 2.7 & 0 & 6.5 & 2.6 & 0 & 11.3 & 4.7 & 0 & 4.8 & 2.0 \\
\hline $\begin{array}{l}\text { Joint with } \\
\text { other } \mathrm{HH} \\
\text { member }\end{array}$ & 0 & 1.6 & 0.7 & 0 & 4.8 & 2.0 & 0 & 6.5 & 2.6 & 0 & 1.6 & 0.7 & 0 & 1.6 & 0.7 \\
\hline $\begin{array}{l}\text { Mainly/only } \\
\text { other HH } \\
\text { member }\end{array}$ & 0 & 8.1 & 3.3 & 0 & 8.1 & 3.3 & 0 & 6.5 & 2.6 & 0 & 6.4 & 2.7 & 0 & 9.7 & 4.0 \\
\hline $\mathrm{N}$ & 89 & 62 & 151 & 89 & 62 & 151 & 89 & 62 & 151 & 89 & 62 & 151 & 89 & 62 & 151 \\
\hline
\end{tabular}

Table 6: Gender and the Management of Poultry (Ducks and Geese); source: Original Research

\begin{tabular}{|c|c|c|c|c|c|c|c|c|c|c|c|c|c|c|c|}
\hline \multirow[b]{2}{*}{ (\%age) } & \multicolumn{3}{|c|}{$\begin{array}{l}\text { Who decides to raise } \\
\text { these animals? }\end{array}$} & \multicolumn{3}{|c|}{$\begin{array}{l}\text { Who bargains the } \\
\text { price when buying? }\end{array}$} & \multicolumn{3}{|c|}{$\begin{array}{l}\text { Who takes primary } \\
\text { care? }\end{array}$} & \multicolumn{3}{|c|}{$\begin{array}{l}\text { Who decides when to } \\
\text { sell the animals? }\end{array}$} & \multicolumn{3}{|c|}{$\begin{array}{l}\text { Who bargains the } \\
\text { price when selling? }\end{array}$} \\
\hline & $\mathbf{M}$ & $\mathbf{F}$ & Total & M & $\mathbf{F}$ & Total & $\mathbf{M}$ & $\mathbf{F}$ & Total & $\mathbf{M}$ & $\mathbf{F}$ & Total & $\mathbf{M}$ & $\mathbf{F}$ & Total \\
\hline Only/mainly man & 33.3 & 18.2 & 28.1 & 28.6 & 18.2 & 25.0 & 14.3 & 9.1 & 12.6 & 28.6 & 0 & 18.8 & 14.3 & 9.1 & 12.6 \\
\hline Joint & 9.5 & 18.2 & 12.5 & 4.8 & 9.1 & 6.3 & 14.3 & 9.1 & 12.5 & 4.8 & 9.1 & 6.3 & 4.8 & 9.1 & 6.3 \\
\hline Only/mainly woman & 52.4 & 36.4 & 46.9 & 66.7 & 45.5 & 59.4 & 66.7 & 36.4 & 56.3 & 66.6 & 63.6 & 65.6 & 80.9 & 54.6 & 71.9 \\
\hline Other HH member & 4.8 & 0 & 3.1 & 0 & 0 & 0 & 4.8 & 18.2 & 9.4 & 0 & 0 & 0 & 0 & 0 & 0 \\
\hline $\begin{array}{l}\text { Only/mainly } \\
\text { respondent }\end{array}$ & 0 & 9.1 & 3.1 & 0 & 0 & 0 & 0 & 9.1 & 3.1 & 0 & 9.1 & 3.1 & 0 & 9.1 & 3.1 \\
\hline $\begin{array}{l}\text { Joint with other } \mathrm{HH} \\
\text { member }\end{array}$ & 0 & 0 & 0 & 0 & 9.1 & 3.1 & 0 & 9.1 & 3.1 & 0 & 0 & 0 & 0 & 0 & 0 \\
\hline $\begin{array}{l}\text { Mainly/only other } \mathrm{HH} \\
\text { member }\end{array}$ & 0 & 18.2 & 6.3 & 0 & 18.2 & 6.3 & 0 & 9.1 & 3.1 & 0 & 18.2 & 6.3 & 0 & 18.2 & 6.3 \\
\hline $\mathrm{N}$ & 21 & 11 & 32 & 21 & 11 & 32 & 21 & 11 & 32 & 21 & 11 & 32 & 21 & 11 & 32 \\
\hline Sig & 0.159 & & & 0.262 & & & 0.271 & & & 0.072 & & & 0.243 & & \\
\hline
\end{tabular}


Table 7: Gender and the Management of Pigs; source: Original Research

\begin{tabular}{|c|c|c|c|c|c|c|c|c|c|c|c|c|c|c|c|}
\hline \multirow[b]{2}{*}{ (\%age) } & \multicolumn{3}{|c|}{$\begin{array}{l}\text { Who decides to raise } \\
\text { these animals? }\end{array}$} & \multicolumn{3}{|c|}{$\begin{array}{l}\text { Who bargains the } \\
\text { price when buying? }\end{array}$} & \multicolumn{3}{|c|}{$\begin{array}{l}\text { Who takes primary } \\
\text { care? }\end{array}$} & \multicolumn{3}{|c|}{$\begin{array}{l}\text { Who decides when to } \\
\text { sell the animals? }\end{array}$} & \multicolumn{3}{|c|}{$\begin{array}{l}\text { Who bargains the } \\
\text { price when selling? }\end{array}$} \\
\hline & M & $\mathbf{F}$ & Total & M & $\mathbf{F}$ & Total & M & $\mathbf{F}$ & Total & $\mathbf{M}$ & $\mathbf{F}$ & Total & M & $\mathbf{F}$ & Tota \\
\hline Only/mainly man & 33.3 & 9.1 & 23.6 & 27.3 & 4.5 & 18.2 & 12.1 & 0 & 7.3 & 30.3 & 4.5 & 20.0 & 21.2 & 4.5 & 14.5 \\
\hline Joint & 12.1 & 9.1 & 10.9 & 9.1 & 9.1 & 9.1 & 27.3 & 18.2 & 23.6 & 15.2 & 4.5 & 10.9 & 3.0 & 0 & 1.8 \\
\hline Only/mainly woman & 48.5 & 45.4 & 47.3 & 57.6 & 54.6 & 56.4 & 45.4 & 50.0 & 47.2 & 45.4 & 63.6 & 52.8 & 66.7 & 63.6 & 65.4 \\
\hline Other HH member & 6.1 & 9.1 & 7.7 & 6.1 & 4.5 & 5.5 & 15.2 & 4.5 & 10.9 & 9.1 & 0 & 5.5 & 9.1 & 4.5 & 7.3 \\
\hline $\begin{array}{l}\text { Only/mainly } \\
\text { respondent }\end{array}$ & 0 & 9.1 & 3.6 & 0 & 4.5 & 1.8 & 0 & 9.1 & 3.6 & 0 & 13.6 & 5.4 & 0 & 13.6 & 5.4 \\
\hline $\begin{array}{l}\text { Joint with other } \mathrm{HH} \\
\text { member }\end{array}$ & 0 & 0 & 0 & 0 & 4.5 & 1.8 & 0 & 9.1 & 3.6 & 0 & 0 & 0 & 0 & 0 & 0 \\
\hline $\begin{array}{l}\text { Mainly/only other } \\
\text { HH member }\end{array}$ & 0 & 18.2 & 7.3 & 0 & 18.2 & 7.3 & 0 & 9.1 & 3.6 & 0 & 13.6 & 5.5 & 0 & 13.6 & 5.5 \\
\hline $\mathrm{N}$ & 33 & 22 & 55 & 33 & 22 & 55 & 33 & 22 & 55 & 33 & 22 & 55 & 33 & 22 & 55 \\
\hline Sig & $0.042^{*}$ & & & 0.076 & & & 0.090 & & & $0.011^{*}$ & & & 0.124 & & \\
\hline
\end{tabular}

Table 8: Gender and the Management of Cattle; source: Original Research

\begin{tabular}{|c|c|c|c|c|c|c|c|c|c|c|c|c|c|c|c|}
\hline \multirow[b]{2}{*}{ (\%age) } & \multicolumn{3}{|c|}{$\begin{array}{l}\text { Who decides to raise } \\
\text { these animals? }\end{array}$} & \multicolumn{3}{|c|}{$\begin{array}{l}\text { Who bargains the } \\
\text { price when buying? }\end{array}$} & \multirow{2}{*}{$\begin{array}{l}\text { Who } \\
\text { care? } \\
\text { M }\end{array}$} & \multicolumn{2}{|c|}{ takes primary } & \multicolumn{3}{|c|}{$\begin{array}{l}\text { Who decides when to } \\
\text { sell the animals? }\end{array}$} & \multicolumn{3}{|c|}{$\begin{array}{l}\text { Who bargains the } \\
\text { price when selling? }\end{array}$} \\
\hline & M & $\mathbf{F}$ & Total & M & F & Total & & $\mathbf{F}$ & Total & M & $\mathbf{F}$ & Total & M & F & Tota \\
\hline $\begin{array}{l}\text { Only/mainly } \\
\text { man }\end{array}$ & 40.3 & 11.7 & 30.0 & 44.2 & 16.3 & 34.2 & 31.2 & 9.3 & 23.3 & 38.2 & 9.3 & 29.7 & 41.6 & 14.0 & 31.7 \\
\hline Joint & 28.6 & 11.6 & 22.5 & 14.3 & 4.7 & 10.8 & 24.7 & 14.0 & 20.8 & 15.8 & 11.6 & 14.3 & 5.2 & 7.0 & 5.8 \\
\hline $\begin{array}{l}\text { Only/mainly } \\
\text { woman }\end{array}$ & 27.3 & 41.9 & 32.5 & 37.7 & 39.5 & 38.3 & 28.6 & 32.5 & 30.0 & 40.7 & 44.2 & 42.0 & 48.1 & 41.9 & 45.8 \\
\hline $\begin{array}{l}\text { Other } \mathrm{HH} \\
\text { member }\end{array}$ & 2.9 & 0 & 25 & 3.9 & 4.7 & 4.2 & 15.6 & 9.3 & 13.3 & 5.3 & 0 & 3.4 & 5.2 & 2.3 & 4.2 \\
\hline $\begin{array}{l}\text { Only/mainly } \\
\text { respondent }\end{array}$ & 0 & 20.9 & 7.5 & 0 & 13.9 & 5.0 & 0 & 13.9 & 5.0 & 0 & 18.6 & 6.7 & 0 & 14.0 & 5.0 \\
\hline $\begin{array}{l}\text { Joint with } \\
\text { other } \mathrm{HH} \\
\text { member }\end{array}$ & 0 & 2.3 & 0.8 & 0 & 4.7 & 1.7 & 0 & 7.0 & 2.5 & 0 & 2.3 & 0.8 & 0 & 2.3 & 0.8 \\
\hline $\begin{array}{l}\text { Mainly/only } \\
\text { other HH } \\
\text { member }\end{array}$ & 0 & 11.6 & 4.1 & 0 & 16.3 & 5.8 & 0 & 14.0 & 5.0 & 0 & 13.9 & 5.0 & 0 & 18.6 & 6.6 \\
\hline $\mathrm{N}$ & 77 & 43 & 120 & 77 & 43 & 120 & 77 & 43 & 120 & 76 & 43 & 119 & 77 & 43 & 120 \\
\hline
\end{tabular}

Table 9: Gender and the Management of Buffaloes; source: Original Research

\begin{tabular}{|c|c|c|c|c|c|c|c|c|c|c|c|c|c|c|c|}
\hline \multirow[b]{2}{*}{ (\%age) } & \multicolumn{3}{|c|}{$\begin{array}{l}\text { Who decides to raise } \\
\text { these animals? }\end{array}$} & \multicolumn{3}{|c|}{$\begin{array}{l}\text { Who bargains the } \\
\text { price when buying? }\end{array}$} & \multirow{2}{*}{$\begin{array}{l}\text { Who } \\
\text { care? } \\
\text { M }\end{array}$} & \multicolumn{2}{|c|}{ takes primary } & \multicolumn{3}{|c|}{$\begin{array}{l}\text { Who decides when to } \\
\text { sell the animals? }\end{array}$} & \multicolumn{3}{|c|}{$\begin{array}{l}\text { Who bargains the } \\
\text { price when selling? }\end{array}$} \\
\hline & $\mathbf{M}$ & $\mathbf{F}$ & Total & M & $\mathbf{F}$ & Total & & $\mathbf{F}$ & Total & M & $\mathbf{F}$ & Total & M & $\mathbf{F}$ & Tota \\
\hline Only/mainly man & 35.3 & 0 & 30.0 & 47.0 & 0 & 40.0 & 23.6 & 0 & 20.0 & 41.1 & 0 & 35.0 & 53.0 & 33.3 & 50.0 \\
\hline Joint & 17.6 & 33.3 & 20.0 & 5.9 & 33.3 & 10.0 & 35.3 & 33.3 & 35.0 & 5.9 & 33.3 & 10.0 & 5.9 & 0 & 5.0 \\
\hline Only/mainly woman & 47.1 & 66.7 & 50.0 & 41.2 & 66.7 & 55.0 & 23.5 & 66.6 & 30.0 & 52.9 & 66.7 & 55.0 & 45.3 & 66.7 & 40.0 \\
\hline Other $\mathrm{HH}$ member & 0 & 0 & 0 & 5.9 & 0 & 5.0 & 17.6 & 0 & 15.0 & 0 & 0 & 0 & 5.9 & 0 & 5.0 \\
\hline $\begin{array}{l}\text { Only/mainly } \\
\text { respondent }\end{array}$ & 0 & 0 & 0 & 0 & 0 & 0 & 0 & 0 & 0 & 0 & 0 & 0 & 0 & 0 & 0 \\
\hline $\begin{array}{l}\text { Joint with other } \mathrm{HH} \\
\text { member }\end{array}$ & 0 & 0 & 0 & 0 & 0 & 0 & 0 & 0 & 0 & 0 & 0 & 0 & 0 & 0 & 0 \\
\hline $\begin{array}{l}\text { Mainly/only other } \mathrm{HH} \\
\text { member }\end{array}$ & 0 & 0 & 0 & 0 & 0 & 0 & 0 & 0 & 0 & 0 & 0 & 0 & 0 & 0 & 0 \\
\hline $\mathrm{N}$ & 17 & 3 & 20 & 17 & 3 & 20 & 17 & 3 & 20 & 17 & 3 & 20 & 17 & 3 & 20 \\
\hline Sig & 0.671 & & & 0.431 & & & 0.627 & & & 0.365 & & & 0.505 & & \\
\hline
\end{tabular}

The roles of men and women are quite noticeable in the management of livestock (Tables 5-9 above), although there is considerable diversity within the sample. Although men are likely to take a leading role in some households in which they are HH, there are many other households in which women (and indeed other household members) seem to be leaders in determining how things take place, how and whether new types of livestock are to be managed and where information is to be sourced. However, it should also be noticed that it is not clear from these results that has the ultimate decision-making power in households - description is not always explanation. When women have responsibility for the livestock concerned, i.e. chickens and poultry, pigs and buffaloes, then their responsibility extends from decision to rise, bargaining when buying and selling and taking primary care. This is in line with the concept that livestock management involves gendered knowledge. This is further emphasized by the fact that joint responsibility is comparatively rare in all of the livestock categories considered.

Information Gathering: If women are to have roles in decision-making in new ways and areas, they must 
have access to some information to help guide those decisions. To investigate the best ways of providing information to respondents, a series of questions was asked concerning their behaviour with respect to information gathering and use. Information-gathering was recorded to be at quite a low rate, with just $16.0 \%$ overall reporting that they had ever sought information about animals at all $(\mathrm{n}=200)$. When considered by animal type, 24 respondents reported that information had been sought on chickens, while the numbers for poultry (4), pigs (15), cattle (12) and others (3) were all quite low. When asked who had searched for this information, the respondents most commonly answered that it was mostly themselves, although it cannot be discounted that they may have been unaware of information-seeking activities by other household members.

Respondents were next asked whether it was easy or difficult to find relevant information about improving livestock management and those who thought it were difficult or very difficult were then quizzed as to where the difficulties were. In fact, $72.0 \%$ of all respondents answered that it was either difficult or very difficult to obtain this kind of information and only $9.0 \%$ thought that it was easy or very easy $(n=200)$. It was very clear what the perceived problem was as $80.8 \%$ of respondents answered that they did not know where to look $(\mathrm{n}=146)$, while there were much smaller levels of support for there being a long way to travel $(8.2 \%)$, for there being no source available (13.7\%), available sources are reluctant to reveal information (0.7\%), available sources are reluctant to speak to women (0.7\%), available sources are not well informed (14.4\%) and other reasons (2.1\%). There is scope, in other words, for improving the availability and quality of information in this area and making it more accessible to respondents and all of the communities considered. Respondents were next asked whether they thought there were many sources of information available about livestock management and $76.0 \%$ thought there were very few or none and only $2.0 \%$ thought there were many $(\mathrm{n}=200)$. Respondents were then asked to nominate the two most important information sources to which they had access, as follows:

Table 12: Sources of Information about Livestock Management; source: Original Research

\begin{tabular}{lll}
\hline \%age & $\begin{array}{l}\text { Most } \\
\text { Important }\end{array}$ & $\begin{array}{l}\text { Second } \\
\text { Important }\end{array}$ \\
\hline Spouse & 12.8 & 1.7 \\
Other Family Member or Friend & 4.8 & 1.7 \\
Field Demonstration Farmers & 1.6 & 0.9 \\
Other Farmers & 14.4 & 18.8 \\
Association of the Product & 3.2 & 5.1 \\
Input Retailers & 8.6 & 3.4 \\
NGOs & 19.8 & 17.1 \\
Radio/TV & 9.1 & 27.4 \\
Government Office & 8.0 & 17.9 \\
Vet & 9.6 & 6.0 \\
Other & 8.1 & 0 \\
$\mathrm{~N}$ & 187 & 117 \\
\hline
\end{tabular}

It is apparent that there is a diverse set of information sources that might be consulted and prominent among them are NGOs, other farmers, radio/TV and government offices. The role of the vet in this process is also worthy of consideration since such people may be called upon for various tasks and can build a relationship with farming households that facilitates information exchange on a range of issues. There is clearly scope for improving the availability and scope of information provided and for advertising what information is available

Discussion: It was posited that better economic development prospects for Cambodia would be achieved through reduced gender inequality and that one way of approaching this would be to examine whether decision-making in agricultural production offered status for women. It has been shown that women have responsibility for all aspects of livestock management in the sample achieved. It was also shown that the types of agricultural activities taking place in a household are determined to some extent by location-specific factors. It has also been shown that there is a need for more and better information about livestock management and, presumably, other aspects of agricultural production. Consequently, the principal that women are entitled to make important decisions has been accepted and this takes place both when women 
are and are not $\mathrm{HH}$. This offers a route for enhanced decision-making power for women in the household. To the extent that livestock management is culturally embedded in terms of gender-specific activities and knowledge, existing knowledge and hence decision-making events belong within the realm of culturally-influenced social relations. It is likely to be a better strategy for development agencies to try to position new decision-making roles within a different sphere of knowledge, in which it will be possible to make decisions according to different approaches. The spread of market forces into what were previously subsistence farming systems may prove to be beneficial in this case. It is also evident that the role of markets in decision-making has not yet reached the level that they might reach. People are making fairly basic decisions which are related to very specific local conditions and do not have the opportunity to make such decisions with relation to the larger perspective that access to international markets and international value chains would suggest. Those companies which would aim to make profits in this market would have a great deal to do to develop the local market so that decision-makers are better able to receive the unique propositions they are able to provide for them.

As a post-conflict country, it might have been expected that new norms could be introduced that would be more in line with the priorities of donor agencies and governments. However, Cambodian society has been recreated in a highly centralized form that has been resistant to processes of decentralization and of localized decision-making (Blunt \& Turner, 2005). This has not been helpful in promoting public participation or pluralism in society and this has had an impact on provision of information to date. This is antithetical to the type of decision-making envisioned here but resolving the issue would require extensive societal change that is unlikely to occur in the foreseeable future. If decision-making is to be seen as a multi-stage process in which information is gathered and evaluated and post-decision evaluation is to take place, then there are various stages at which women can become involved in a process that is not wholly embedded in cultural norms. Bringing about greater involvement for women would be assisted by processes that disassociate them from the culture and recreate social relations on different grounds.

\section{Conclusion}

This paper indicates that there is certainly a gendered division of labor taking place with livestock management and that women have a definite and important role to play in this area. To some extent, this is not surprising since it has been documented previously that the gendered division of labor is extant in Cambodia and that it has been described through the centuries. However, the knowledge that women have a direct impact into decision-making runs counter to various forms of ideological envisaging of the world, relating for example to colonialism and the patriarchy. From a marketing perspective, it is evident first of all that it is important to have sales and distribution agents on the ground close to the potential customers. It has been shown that specific local conditions have a significant impact on the nature and extent of agriculture and so local knowledge will be important. As it has also been shown that women have important roles not just in caring for livestock but also in decision-making, then it is also evident that agents need to be able to access their opinions and the networks that they employ to make sense of the world in order to achieve success in sales. Further exploration of these issues is clearly required. The links between local conditions, class and gender relations and factors leading to uneven development should be further explored. In addition to the usual limitations relating to restrictions on time and place, this study is constrained by the fact that the fieldwork team was deliberately told to find households were $\mathrm{HH}$ and, if that were not possible, nevertheless to ensure that the senior woman in the household was interviewed. As a result, the demographic details of the sample vary significantly from the overall population.

Acknowledgement: This research was funded by CAVAC, an NGO promoting agricultural development in Cambodia and supported by AusAID.

\section{References}

Acharya, M. \& Bennett, L. (1983). Women and the Subsistence Sector: Economic Participation and Household Decision Making in Nepal. World Bank Staff Working Papers, 526.

Asian Development Bank (ADB). (2014). Asian Development Outlook 2014: Fiscal Policy for Inclusive Growth. Manila: ADB. 
Baumeister, R. F. (2002).Yielding to Temptation: Self-Control Failure, Impulsive Purchasing and Consumer Behavior. Journal of Consumer Research, 28(4),670-6.

Belk, R. W. (1975). Situational Variables and Consumer Behavior. Journal of Consumer Research, 2(3), 157-64.

Blunt, P. \& Turner, M. (2005). Decentralization, Democracy and Development in a Post-Conflict Society: Commune Councils in Cambodia. Public Administration and Development, 25(1),75-87.

Budlender, D. (2003). The Debate about Household Headship, Social Dynamics. A Journal of African Studies, 29(2),48-72.

Chan, R. \& Chheang, V. (2008).Cultural Challenges to the Decentralization Process in Cambodia. The Ritsumeikan Journal of Asia Pacific Studies, 24,1-16.

Daguan, Z. (2007). A Record of Cambodia: The Land and Its People, translated with an introduction by Peter Harris. Chiang Mai: Silkworm Books.

Davidson, P. (1982). Rational Expectations: A Fallacious Foundation for Studying Crucial Decision-Making Processes. Journal of Post Keynesian Economics, 5(2),182-98.

Davis, H. L. (1976). Decision Making within the Household. Journal of Consumer Research, 2(4),241-60.

De Jong, G. F. (2000). Expectations, Gender, and Norms in Migration Decision-Making. Population Studies: A Journal of Demography, 54(3),307-19.

Donovan, R. J., Rossiter, J. R., Marcoolyn, G. \& Nesdale, A. (1994). State Atmosphere and Purchasing Behavior. Journal of Retailing, 70(3),283-94.

Edwards, W. (1954).The Theory of Decision Making. Psychological Bulletin, 51(4),380-417.

Hoggart, R. (1996). The Way We Live Now: Dilemmas in Contemporary Culture, new ed. London: Pimlico.

Jacobsen, T. (2008). Lost Goddesses: The Denial of Female Power in Cambodian History. Copenhagen: NIAS Press.

Karl, M. (1995).Women and Empowerment: Participation and Decision-Making. London: UN NGLS/Zed Books.

Klein, G. \& Zsambok, C. C. (1997). Naturalistic Decision Making. Mahwah, NJ: Erlbaum, Lawrence, Associates.

Kriti, T. W., Tisdell, C. \& Roy, K. C. (2003). Female Participation in Decision Making in Agricultural Households in Kenya: Empirical Findings. International Journal of Agricultural Resources, Governance and Ecology, 2(2),103-24.

Lovichakorntikul, P., Ngamsang, S. \& Walsh, J. (2013).The Impact of Agricultural Input Change on Gendered Decision-Making in Rice-Farming Households in Thailand and Cambodia. Paper presented at the $3^{\text {rd }}$ International Conference on International Relations and Development, Chulalongkorn University, Bangkok.

Manser, M. \& Brown, M. (1980). Marriage and Household Decision-Making: A Bargaining Analysis. International Economic Review, 21(1),31-44.

Reynolds, T. J. \& Gutman, J. (1988).Laddering Theory, Method, Analysis, and Interpretation. Journal of Advertising Research, 28(1),11-31.

Rocheleau, D. E. (1991). Gender, Ecology, and the Science of Survival: Stories and Lessons from Kenya. Agriculture and Human Values, 8(1-2), 156-65.

Scott, J. C. (1976). The Moral Economy of the Peasant: Rebellion and Subsistence in South East Asia. New Haven, CT: Yale University Press.

Simon, H. A. (1955). A Behavioral Model of Rational Choice. Quarterly Journal of Economics, 69, 99-118.

Thakur, R. \& Walsh, J. (2013). Space and Workplace Issues for Nepalese Female Entrepreneurs. Paper presented at the International Conference on Economics and Social Sciences, First Hotel, Bangkok.

Venkatesh, V., Morris, M. G. \& Ackerman, P. L. (2000). A Longitudinal Field Investigation of Gender Differences in Individual Technology Adoption Decision-Making Processes. Organizational Behavior and Human Decision Processes, 83(1),33-60.

World Bank. (2012). World Development Report 2012: Gender Equality and Development, Washington, DC: World Bank.

Yisehak, K. (2008). Gender Responsibility in Smallholder Mixed Crop-Livestock Production Systems of Jimma Zone, South West Ethiopia. Livestock Research for Rural Development, 20(1),available at: http://www.lrrd.cipav.org.co/lrrd20/1/yise20011.htm. 